\title{
CYCLOPIDAE (CRUSTACEA, COPEPODA) FROM THE UPPER PARANÁ RIVER FLOODPLAIN, BRAZIL
}

\author{
LANSAC-TÔHA, F. A., VELHO, L. F. M., HIGUTI, J. and TAKAHASHI, E. M. \\ Universidade Estadual de Maringá, Nupélia, Department of Biology, \\ Postgraduate Course in Ecology of Continental Aquatic Environments, \\ Av. Colombo, 5790, CEP 87020-900, Maringá, PR, Brazil \\ Correspondence to: Fábio Amodêo Lansac-Tôha, Universidade Estadual de Maringá, Nupélia, \\ Department of Biology, Postgraduate Course in Ecology of Continental Aquatic Environments, \\ Av. Colombo, 5790, CEP 87020-900, Maringá, PR, Brazil, e-mail: fabio@ nupelia.uem.br \\ Received March 24, 2000 - Accepted November 29, 2000 - Distributed February 28, 2002
}

(With 6 figures)

\begin{abstract}
Cyclopid copepods from samples of fauna associated with aquatic macrophytes and plancton obtained in lotic and lentic environments were obtained from the upper Paraná River floodplain (in the states of Paraná and Mato Grosso do Sul, Brazil). Macrophytes were collected in homogeneous stands and washed. Plankton samples, taken from the water column surface and bottom, were obtained using a motor pump, with a $70 \mu \mathrm{m}$ mesh plankton net for filtration. Twelve taxa of Cyclopidae were identified. Among them, Macrocyclops albidus albidus, Paracyclops chiltoni, Ectocyclops rubescens, Homocyclops ater, Eucyclops solitarius, Mesocyclops longisetus curvatus, Mesocyclops ogunnus, and Microcyclops finitimus were new finds for this floodplain. Eight species were recorded exclusively in aquatic macrophyte samples. Among these species, M. albidus albidus and M. finitimus presented greatest abundances. Only four species were recorded in plankton samples, and Thermocyclops minutus and Thermocyclops decipiens are limited to this type of habitat. Among these four species, T. minutus is the most abundant, especially in lentic habitats.
\end{abstract}

Key words: Cyclopidae, taxonomy, phytophyle fauna, zooplankton, Paraná River.

\section{RESUMO}

\section{Cyclopidae (Crustacea, Copepoda) da planície de inundação do alto rio Paraná, Brasil}

Foram obtidos copépodes cyclopídeos de amostras de fauna associadas a macrófitas aquáticas e plâncton de ambientes lóticos e lênticos da planície de inundação do alto rio Paraná (nos Estados do Paraná e Mato Grosso do Sul). As amostras foram coletadas em bancos homogêneos e lavadas. As amostras de plâncton, tomadas à superfície e fundo da coluna de água, foram obtidas com o auxílio de uma motobomba, utilizando-se uma rede de plâncton de abertura de malha de $70 \mu \mathrm{m}$ para filtração. Doze táxons de Cyclopidae foram identificados. Entre eles, Macrocyclops albidus albidus, Paracyclops chiltoni, Ectocyclops rubescens, Homocyclops ater, Eucyclops solitarius, Mesocyclops longisetus curvatus, Mesocyclops ogunnus e Microcyclops finitimus representam novos registros para essa planície. Oito espécies foram registradas exclusivamente em amostras de macrófitas aquáticas. Entre essas, M. albidus albidus e M. finitimus são as mais abundantes. Somente quatro espécies foram registradas em amostras de plâncton, e Thermocyclops minutus e Thermocyclops decipiens são exclusivas para esse tipo de habitat. Dessas quatro espécies, T. minutus é a mais abundante, especialmente em ambientes lênticos.

Palavras-chave: Cyclopidae, taxonomia, fauna fitófila, zooplâncton, rio Paraná. 


\section{INTRODUCTION}

In Brazil, studies of cyclopid copepods have traditionally been dealt with prior to their biological and ecological aspects. Among the studies developed about taxonomic aspects, those undertaken by Reid (1985) include the development of identification keys and list of references for South American freshwater species. Recently, Rocha \& Botelho (1998) reviewed cyclopoid species recorded in Brazil, providing information on taxonomy and geographical distribution of the species.

Research was carried out in the floodplain of the upper Paraná River, and species composition of cyclopid copepods from samples of both fauna associated with aquatic macrophyte and plankton are described.

\section{MATERIAL AND METHODS}

Cyclopid copepods from Eichhornia azurea Kunth associated fauna and plankton samples were obtained from lotic and lentic environments from the upper Paraná River floodplain, states of Paraná

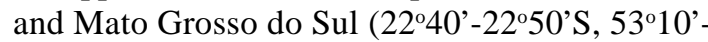
$53^{\circ} 40^{\prime} \mathrm{W}$ ), Brazil (Fig. 1), from March 1992 to February 1993. Macrophytes were collected in homogeneous stands washed in pails with formaldehyde $4 \%$ solution. Plankton samples were obtained by horizontal and vertical hauls and a pump. A plankton net, mesh size of $70 \mu \mathrm{m}$ for filtration, was used. Samples were taken at different depths in the pelagic region and from the surface of the littoral region.

For identification of different taxa, organisms were separated, mounted on slides with glycerin, analyzed, and measured by Wild M20 microscope. Sketches of organisms were made with a drawing tube. Measurements were taken with a pre-calibrated micrometric eyepiece. In the case of Ectocyclops rubescens (Brady), males were also used.

Material was placed in the zooplankton laboratory of the Research Nucleus in Limnology, Ichthology, and Aquaculture of the Universidade Estadual de Maringá, Maringá, Paraná, Brazil.

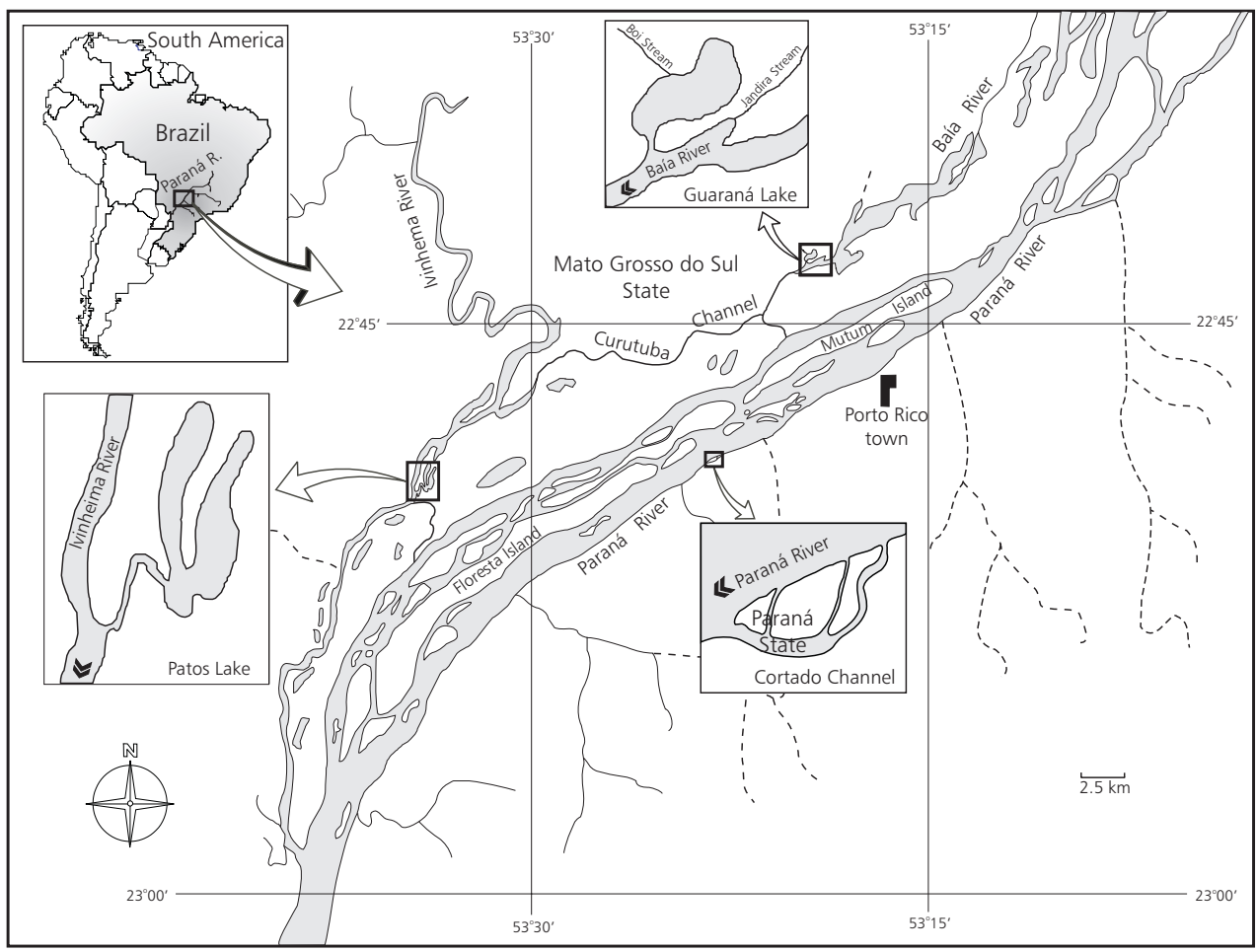

Fig. 1 - Study área. 


\section{RESULTS}

Ectocyclops rubescens Brady, 1904 (Fig. 2a, b, c) Herbst, 1962: 268-269, figs. 24-31; Reid, 1985: 35, fig. 4; Morton, 1990: 670-672, fig. 7.

Commentaries: This species is common in samples of fauna associated with aquatic macrophytes from lentic and lotic environments of the upper Paraná River floodplain. It was not registered in plankton samples. This is the first record for the upper Paraná River floodplain.

Eucyclops solitarius Herbst, 1959 (Fig. 2d, e, f) Herbst, 1959: 49, figs. 1-4; Reid, 1985: 39, figs. 121-123; Defaye \& Dussart, 1988: 118, figs. 8187.
Commentaries: E. solitarius is rare in the upper Paraná River floodplain. It had only been registered only in samples of fauna associated with aquatic macrophytes from lentic and lotic environments. This is the first record for this floodplain.

Homocyclops ater (Herrick, 1882) (Fig. 2g, h, i, j)

Reid, 1985: 31, figs. 59-61; Fallavena, 1985, fig. 6 (as Macrocyclops ater); Montú \& Goeden, 1986: 111, fig. 34 (as Macrocyclops ater).

Commentaries: Rare species in the upper Paraná River floodplain. It had only been registered in samples of fauna associated with aquatic macrophytes from lentic environments. This is the first record for the upper Paraná River floodplain.
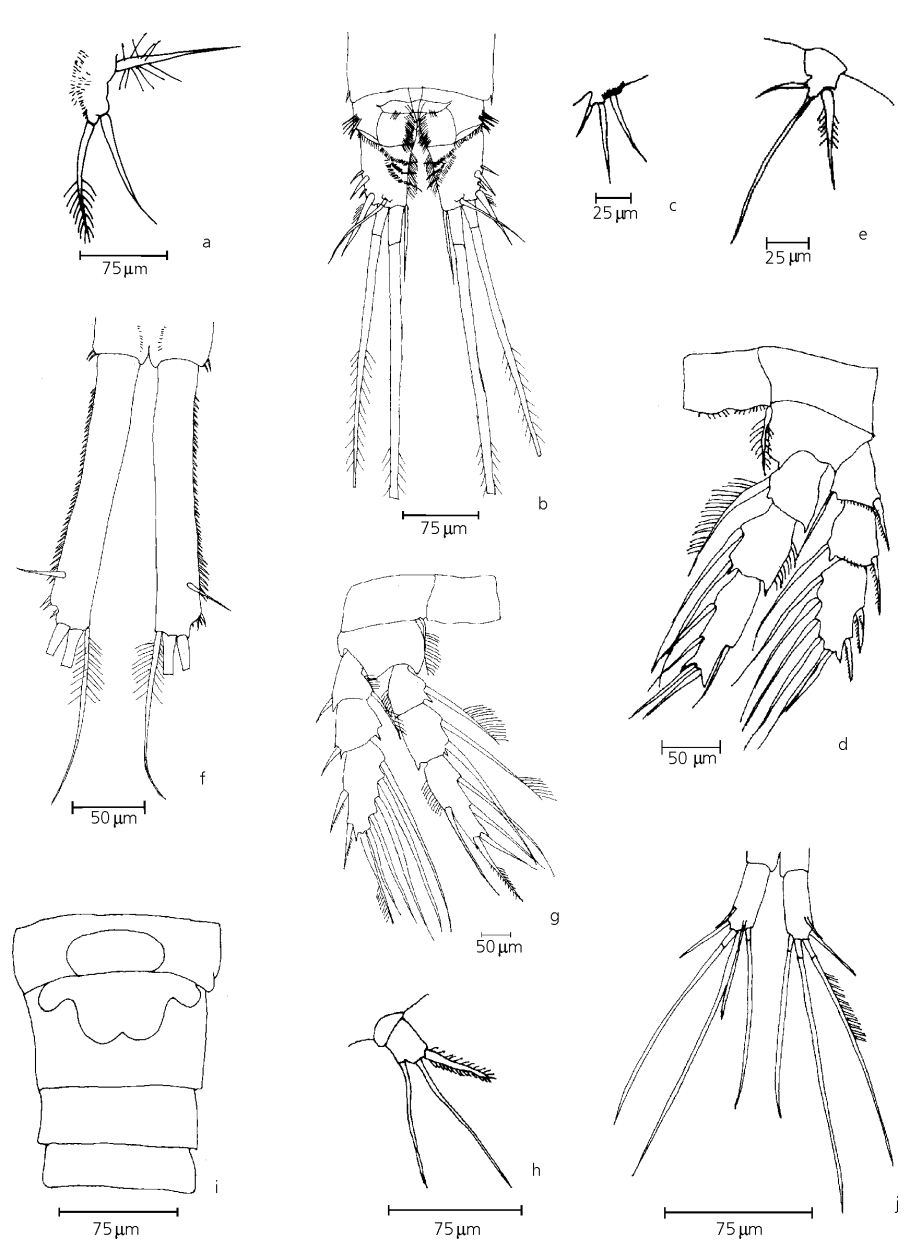

Fig. 2 - a-c) Ectocyclops rubescens (female): a) P5; b) caudal rami, male: c) P6; d-f) Eucyclops solitarius (female): d) P4; e) P5; f) caudal rami; g-j) Homocyclops ater (female): g) P4; h) P5; i) seminal receptacle and abdominal segments; j) caudal rami. 
Macrocyclops albidus albidus (Jurine, 1820) (Fig. 3a, b, c, d)

Dussart, 1984: fig. 13; Reid, 1985: 32, figs. 6669; Fallavena, 1985, fig. 5 (as M. albidus); Montú \& Goeden, 1986: 116, fig. 35-i (as M. albidus); Chengalath \& Shih, 1994: 2425-2426, fig. 3.

Commentaries: Abundant species in the floodplain in samples of fauna associated with aquatic macrophytes; greater abundance in lotic environments. It had not been recorded in plankton samples. This is the first record for the upper Paraná River floodplain.
Paracyclops chiltoni (Thomson, 1882) (Fig. 3 e, $\mathbf{f}, \mathbf{g}, \mathbf{h})$

Smith \& Fernando, 1978: 2022, figs. 40-42; Reid, 1985: 34, fig. 75; Dussart \& Frutos, 1986: pl. IX, figs. 60-61; Suárez-Morales et al., 1996: 179, fig.62; Karaytug \& Boxshall, 1998: 590-598, figs. 17-23.

Commentaries: This species is common in the upper Paraná River floodplain in samples of fauna associated with aquatic macrophytes from lentic and lotic environments. It had not been recorded in plankton samples. This is the first record of the species for this floodplain.
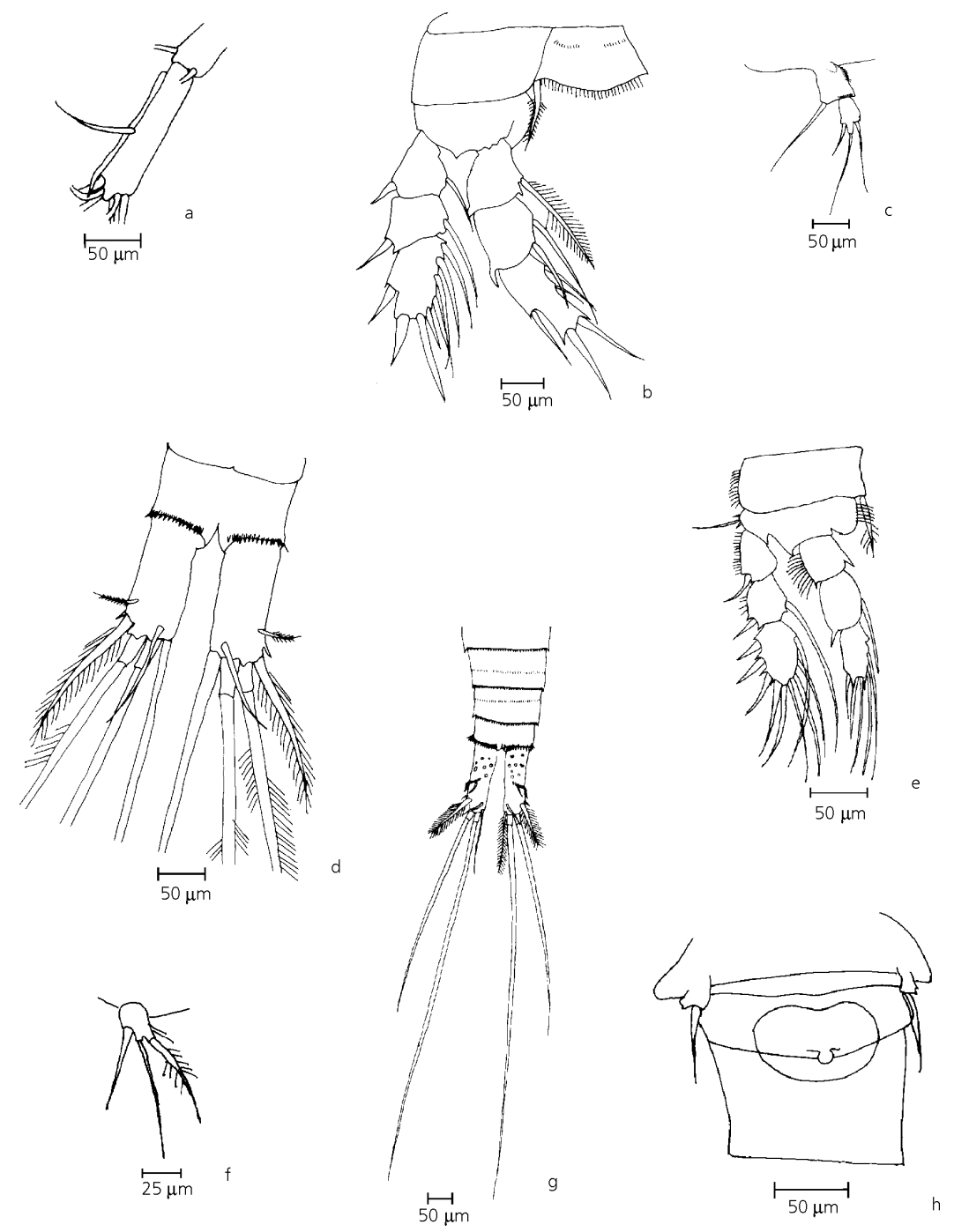

Fig. 3 - a-d) Macrocyclops albidus albidus (female): a) terminal segment of antennule; b) P4; c) P5; d) caudal rami; e-h) Paracyclops chiltoni (female): e) P4; f) P5; g) genital segment with seminal receptacle; h) caudal rami. 
Mesocyclops meridianus (Kiefer, 1926) (Fig. 4a, b, c)

Dussart, 1984: 60, fig. 26; 1987: 152, figs. 2735; Reid, 1985: 45-46, figs. 183-186; Dussart \& Frutos, 1985: 313, figs. 56-59; Silva et al., 1989: 729, figs. 155-183; Reid \& Pinto Coelho, 1994: 361.

Commentaries: Frequent and abundant species in lentic and lotic environments of the upper Paraná River floodplain in samples of fauna associated with aquatic macrophytes, with greater abundances in lentic environments. It has been recorded in plankton samples, but in low frequence and abundance.

\section{Mesocyclops ogunnus Onabamiro, 1957 (Fig. 4d,} $\mathbf{e}, \mathbf{f}, \mathbf{g}, \mathbf{h}, \mathbf{i})$

Onabamiro, 1957: 125, figs. 7-12; Dussart \& Fernando, 1988: 241, 250-251, figs. 28-30; Boxshall \& Braide, 1991: 208-209, 212, fig. 64; Reid \& Kay, 1992: 331, 336-339, fig. 3d-f; Reid \& Pinto-Coelho, 1994: 360-361.
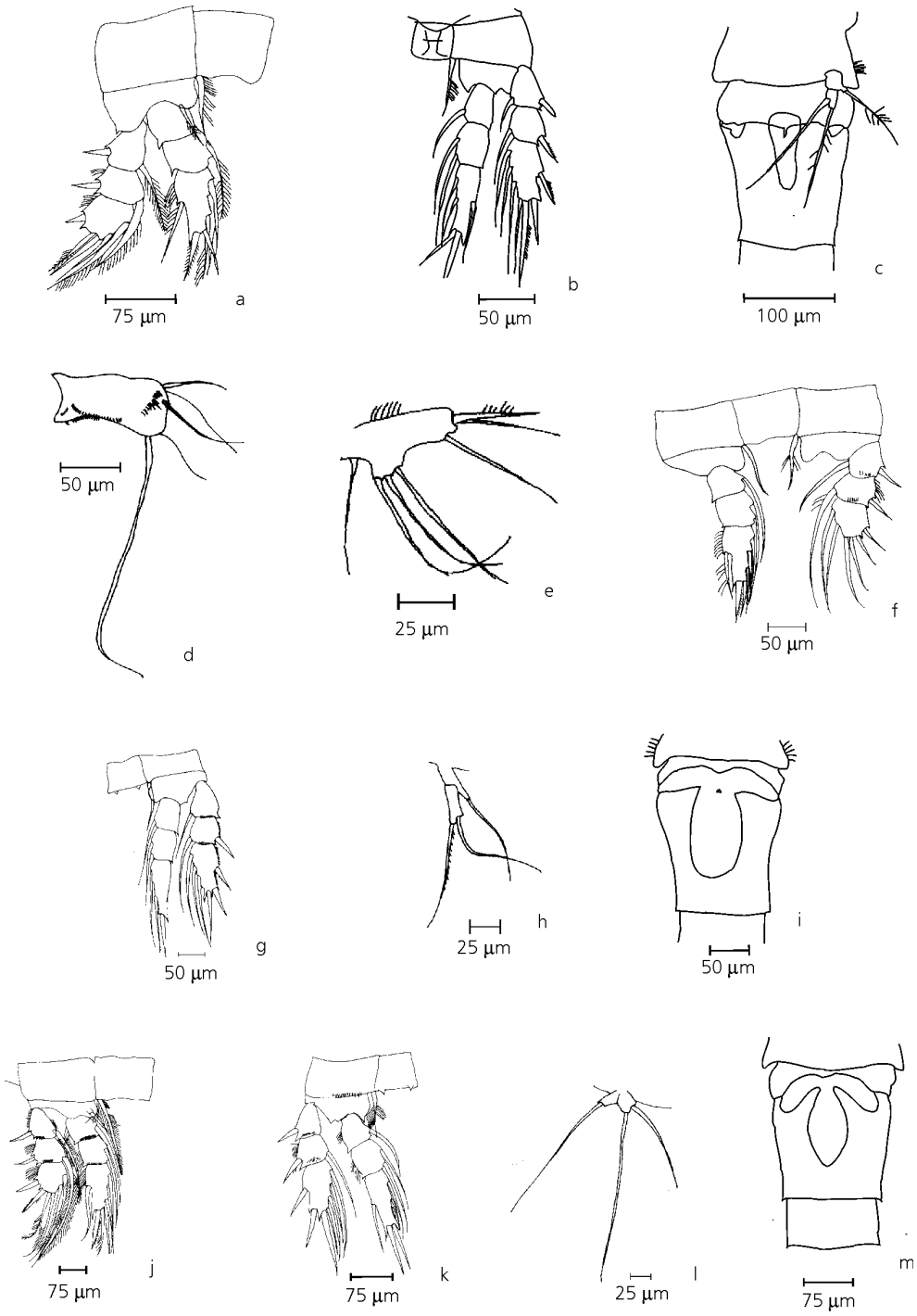

Fig. 4 - a-c) Mesocyclops meridianus (female): a) P1; b) P4; c) genital segment with seminal receptacle and P5; d-i) Mesocyclops ogunnus (female): d) basipodite of antenna; e) maxillular palp; f) P1; g) P4; h) P5; i) pediger 5 and genital segment with seminal receptacle; j-m) Mesocyclops longisetus curvatus (female): j) P1; k) P4; 1) P5; m) genital segment with seminal receptacle. 
Commentaries: M. ogunnus, an Afro-Asian species recently introduced into Brazil, in Furnas Reservoir situated in the south of Minas Gerais, partly bordering São Paulo State (Reid \& Pinto-Coelho, 1994). Rare in lentic and lotic environments of the upper Paraná River floodplain, and recorded only in samples of fauna associated with aquatic macrophytes. It is the first record for this floodplain.

\section{Mesocyclops longisetus curvatus Dussart, 1987} (Fig. 4j, k, l, m)

Dussart, 1987: 150, 156, figs. 3-4, 7-8; Reid \& Reed, 1994: 80-82, figs. 1-2; Reid \& Pinto-Coelho, 1994: 367;

Suárez-Morales et al., 1996: 12, figs. 33-35, 89 a-b.

Commentaries: This species is common in the upper Paraná River floodplain, in samples of fauna associated with aquatic macrophytes. Greater abundance in lentic environments. This is the first register for this floodplain.

Microcyclops anceps anceps (Richard, 1897) (Fig. 5a, b, c, d, e, f)

Richard, 1897: 265, figs. 1-4; Sendacz \& Kubo, 1982: 81, figs. $72-75$ (as $M$. anceps); Matsumura-Tundisi \& Rocha, 1983: fig. VI (as M. anceps); Reid, 1985: 54, figs. 4-16; Rocha, 1998: 427-429, pl. I, figs. 12 , pl. II, fig. 13, pl. III, fig. 17.
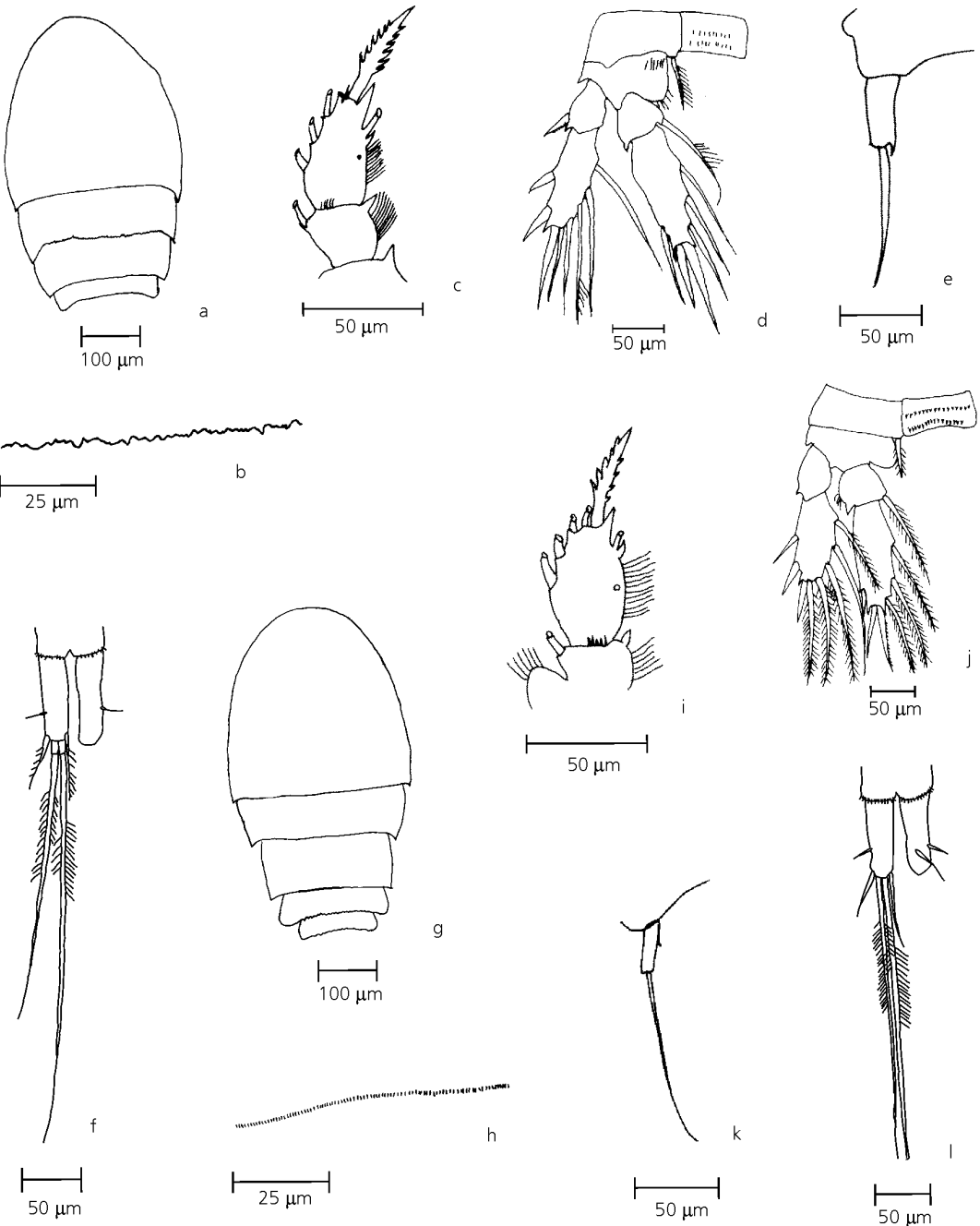

Fig. 5 - a-f) Microcyclops anceps anceps (female): a) dorsal view of prosomal somites; b) detail of posterior border of second prosomal somite; c) frontal view of terminal segment of P1 endopod; d) P4; e) P5; f) caudal rami and setae; g-1) Microcyclops finitimus (female): $\mathrm{g}$ ) dorsal view of prosomal somites; $\mathrm{h}$ ) detail of posterior border of fourth prosomal somite; i) frontal view of terminal segment of P1 endopod; j) P4; k) P5; 1) caudal rami and setae. 
Commentaries: Frequent species in the floodplain with greater abundance in lentic environments, especially in samples of fauna associated with aquatic macrophytes.

\section{Microcyclops finitimus Dussart, 1984 (Fig. 5g,} $\mathbf{h}, \mathbf{i}, \mathbf{j}, \mathbf{k}, \mathbf{l}$, )

Dussart, 1984: 57-58, fig. 19A; Silva et al., 1989: 729, figs. 184-197; Rocha, 1998: 427-429, pl. I, fig. 7, pl. II, fig. 12, pl. III, fig. 18.

Commentaries: Abundant species in lentic and lotic environments of the upper Paraná River floodplain in fauna associated with aquatic macrophytes. It had not been recorded in plankton samples. This is the first register for the upper Paraná River floodplain.

Thermocyclops decipiens (Kiefer, 1929) (Fig. 6a, b, c)

Sendacz \& Kubo, 1982: 75-76, figs. 44-57 (as $T$. crassus); Reid, 1985: 49, figs. 224-227; Defaye et al., 1987: 3145, figs. 11-19.

Commentaries: Frequent and abundant species in plankton samples of the upper Paraná River floodplain.
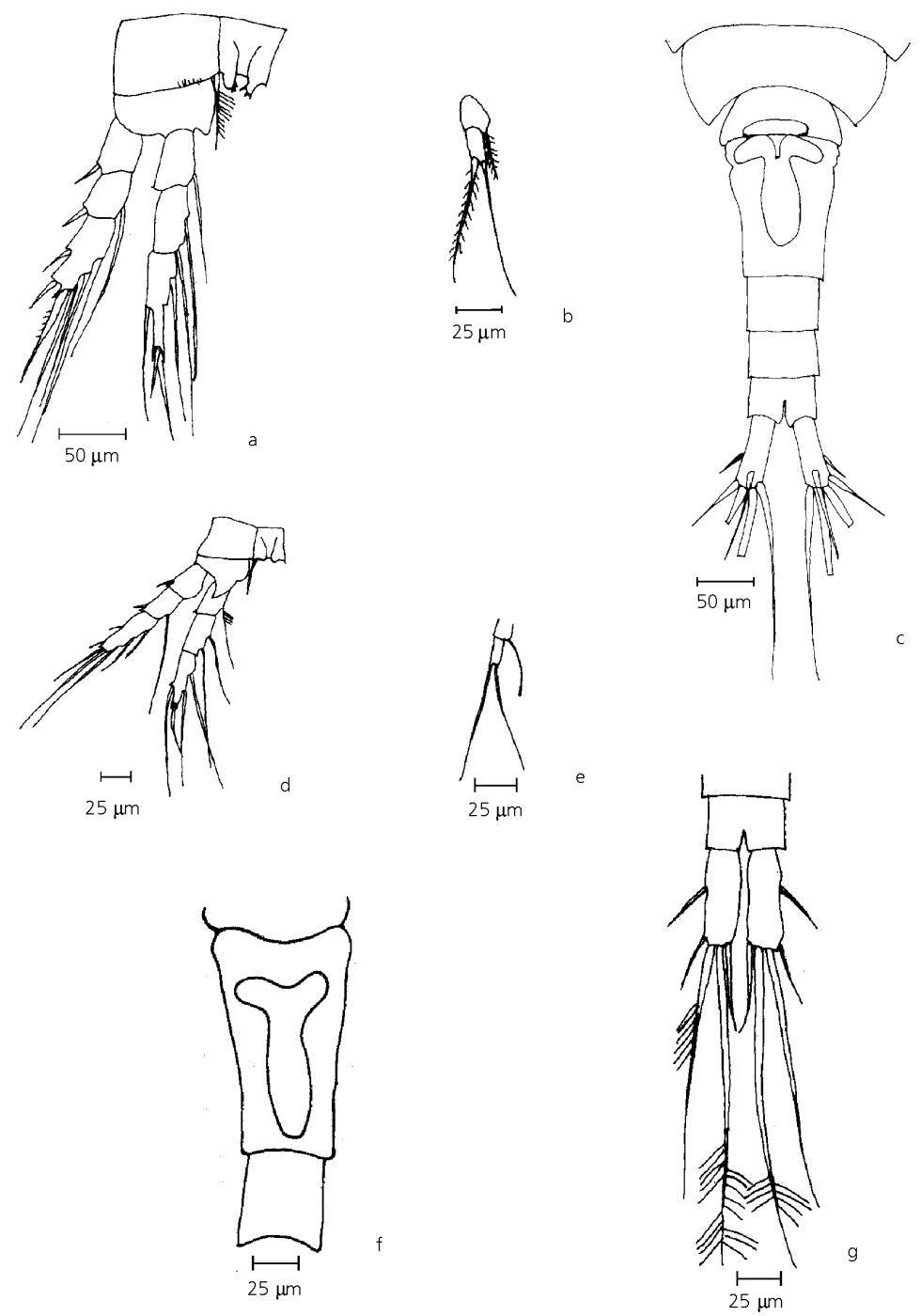

Fig. 6 - a-c) Thermocyclops decipiens (female): a) P4; b) P5; c) genital segment with seminal receptacle, abdominal segments and caudal rami; d-g) Thermocyclops minutus (female): d) P4; e) P5; f) genital segment with seminal receptacle; g) caudal rami. 
Greatest densities have been registered in lentic environments.

\section{Thermocyclops minutus (Lowndes, 1934) (Fig. 6d, e, f, g)}

Lowndes, 1934: 113, fig. 10 (as Mesocyclops minutus); Sendacz \& Kubo, 1982: 76, figs. 5156; Matsumura-Tundisi \& Rocha, 1983, figs. I. 2; Reid, 1985: 49, figs 217-219.

Commentaries: T. minutus is the most frequent and abundant species of copepods in plankton samples of the upper Paraná River floodplain. Greatest abundance of this species is in lentic environments.

\section{DISCUSSION}

Species richness of cyclopoid copepods associated with Eichhornia azurea was greater than that found in plankton samples collected in the same type of habitats from the upper Paraná River floodplain.

Among the most frequent and abundant species of phytophile fauna, such as Microcyclops anceps anceps, $M$. finitimus, Macrocyclops albidus albidus, and Mesocyclops meridianus, only $M$. anceps anceps and $M$. meridianus have been recorded in low frequency and low abundance in plankton samples. Inversely, the most frequent and abundant species in the plankton, Thermocyclops minutus and T. decipiens were not found associated with E. azurea.

Paggi (pers. comm.) suggested that there is a transversal gradient of abundance in which cyclopids increase in richness and abundance from the pelagic region toward the littoral region.

According to McLachlan (1969), predadors seem to be favored by the great compactness of aquatic macrophyte banks. In the present study the occurrence of many predatory cyclopid species suggests the use of macrophytes as hiding place (Strixino \& Strixino, 1984). The animals might better exercise their predatory strategies in those banks.

Acknowledgments - We thank Prof. Dr. William M. Silva for suggestions and comments, Prof. Dr. Luiz Carlos Gomes for assistance with the English text, and Prof. Dr. Alice Michiyo Takeda for supplying Cyclopidae from aquatic macrophyte samples. This study was supported by PADCT/CIAMB and NUPELIA/UEM.

\section{REFERENCES}

BOXSHALL, G. A. \& BRAIDE, E. I., 1991, The freshwater cyclopoid copepods of Nigeria, with an illustrated key to all species. Bull. Br. Mus. Nat. Hist. Zool., 57: 185-212.

CHENGALATH, R. \& SHIH, C., 1994, Littoral freshwater copepods of northwestern North America: Northern British Columbia. Verh. Internat. Verein. Limnol., 25: 2421-2431.

DEFAYE, D., DUSSART, B. H., FERNANDO, C. H. \& SAMITA, A. S., 1987, On some species of the genus Thermocyclops (Crustacea, Copepoda) from the Oriental Region. Can. J. Zool., 65: 3144-3153.

DEFAYE, D. \& DUSSART, B. H., 1988, Compléments à la fauna des Crustacés copépodes des eaux intérieurs de Guyane Française. Rev. Hydrobiol. Trop., 21: 109-125.

DUSSART, B. H., 1984, Some Crustacea Copepoda from Venezuela. Hydrobiologia, 113: 15-23.

DUSSART, B. H., 1987, Sur quelques Mesocyclops (Crustacea, Copepoda) d'Amerique du Sud. Amazoniana, 10: 149-161.

DUSSART, B. H. \& FRUTOS, S. M., 1985, Sur quelques copépodes d'Argentine. Rev. Hydrobiol. Trop., 18: $305-$ 314

DUSSART, B. H. \& FRUTOS, S. M., 1986, Sur quelques copépodes d'Argentine. 2. Copépodes du Paraná Médio. Rev. Hydrobiol. Trop., 19: 241-262.

DUSSART, B. H. \& FERNANDO, C. H., 1988, Sur quelques Mesocyclops (Crustacea, Copepoda). Hydrobiologia, 157: 241-264.

FALLAVENA, M. A. B., 1985, Composição e variações sazonal e espacial dos copépodos planctônicos (Crustacea, Copepoda) na lagoa Negra, Município de Viamão, Rio Grande do Sul, Brasil. Iheringia, 65: 3-30.

HERBST, H. V., 1959, Brasilianische Süsswassercyclopoiden (Crustacea Copepoda). Gewäss Abwäss, 24: 49-73.

HERBST, H. V., 1962, Crustacea aus dem Amazonnasgebiet, gesammelt von Professor Dr. H. Sioli und Dr. R. Braun. 1. Litorale und substratgebundene Cyclopoida Gnathostoma (Copepoda). Crustaceana, 3: 259-278.

KARAYTUG, S. \& BOXSHALL, G. A., 1998, The Paracyclops fimbriatus-complex (Copepoda, Cyclopoida): a revision. Zoosystema, 20: 563-602.

LOWNDES, A. G., 1934, Reports of an expedition to Brazil and Paraguay in 1926-7 supported by the Trustees of the Percy Sladen Memmorial Fund and the Executive Committee of the Carnegie Trust for Scotland. Copepoda. J. Limn. Soc. Zool., 39: 83-131.

MATSUMURA-TUNDISI, T. \& ROCHA, O., 1983, Occurrence of copepod (Calanoida, Cyclopoida and Harpacticoida) from "Broa" Reservoir (São Carlos, São Paulo, Brazil). Rev. Bras. Biol., 43: 1-17. 
McLACHLAN, A. J., 1969, The effect of aquatic macrophytes on the variety and abundance of benthic fauna in newly created lake in the tropics (Lake Kariba). Arch. Hydrobiol., 62: 212-231.

MONTÚ, M. \& GOEDEN, I. M., 1986, Atlas dos Cladocera e Copepoda (Crustacea) do estuário da lagoa dos Patos (Rio Grande do Sul, Brasil). Nerítica, 1: 1-134.

MORTON, D. W., 1990, Revision of the Australian Cyclopidae (Copepoda: Cyclopoida). II. Eucyclops Claus and Ectocyclops Brady. Aust. J. Mar. Fresh. Res., 41: 657-675.

ONABAMIRO, S. D., 1957, Some new species of Cyclops sensu-lat. (Crustacea: Copepoda) from Nigeria. J. Linn. Soc. Lond. Zool., 43: 123-133.

REID, J. W., 1985, Chave de identificação e lista de referências bibliográficas para as espécies continentais sul-americanas de vida livre da Ordem Cyclopoida (Crustacea, Copepoda). Bolm Zool., São Paulo, 9: 17:143.

REID, J. W. \& KAY, B. H., 1992, Mesocyclops guangxiensis, new species, and new records of four congeners (Crustacea: Copepoda: Cyclopidae) from China, Laos and Viet Nam. Proc. Biol. Soc. Wash., 105: 331-342.

REID, J. W. \& REED, E. B., 1994, First records of two neotropical species of Mesocyclops (Copepoda) from Yukon Territory: cases of passive dispersal? Arctic, 47: 80-87.

REID, J. W. \& PINTO-COELHO, R. M., 1994, An afro-asian continental copepod, Mesocyclops ogunnus, found in Brazil; with a new key to the species of Mesocyclops in South America and a review of intercontinental introductions of copepods. Limnologica, 24: 359-368.
RICHARD, J., 1897, Entomostracés de l'Amerique du Sud, recueillis par M. U. Dieters, H. von Ihering, G. W. Muller et C. O. Poppe. Mem. Soc. Zool. France, 10: 263-301.

ROCHA, C. E. F., 1998, New morphological characters useful for the taxomomy of the genus Microcyclops (Copepoda, Cyclopoida). J. Mar. Syst., 15: 425-431.

ROCHA, C. E. F. \& BOTELHO, M. J. C., 1998, MaxillopodaCopepoda Cyclopoida. In: P. S. Young (ed.), Catalogue of crustacea of Brazil. Museu Nacional, Rio de Janeiro (Série Livros $\mathrm{n}^{-}$6).

SENDACZ, S. \& KUBO, E., 1982, Copepoda (Calanoida e Cyclopoida) de reservatórios do Estado de São Paulo. Bol. Inst. Pesca, 9: 51-89.

SILVA, E. N. S., ROBERTSON, B. A., REID, J. L. W. \& HARDY, E. R., 1989, Atlas de copépodos planctônicos, Calanoida e Cyclopoida (Crustacea), da Amazônia Brasileira. I. Represa de Curuá-Una, Pará. Rev. Bras. Zool., 6: 725-758.

SMITH, K. \& FERNANDO, C. H., 1978, The freshwater calanoid and cyclopoid copepod Crustacea of Cuba. Can. J. Zool., 56: 2015-2023.

STRIXINO, G. \& STRIXINO, S. T., 1984, Macroinvertebrados associados a macrófitas aquáticas das lagoas marginais da estação ecológica de Jataí (Luiz AntônioSP). Anais, Seminário Regional de Ecologia, São Carlos, SP, 8: 1189-1198.

SUÁREZ-MORALES, E., REID, J. W., ILIFFE, T. M. \& FIERS, F., 1996, Catálogo de los copépodos (Crustacea) continentales de la Península de Yucatán, México. ECOSUR/CONABIO, Ciudad del México. 